\title{
Offshore Wind Power Plant in the Adriatic Sea: An Opportunity for the Croatian Economy
}

\author{
Božidar Liščić, Ivo Senjanović, Većeslav Čorić, \\ Hrvoje Kozmar, Marko Tomić, Neven Hadžić
}

The significant growth of renewable energy production in the past decades is present mainly due to the global depletion of fossil fuel reserves. One of interesting and well developed renewable energy technologies are wind turbines which are mainly built onshore. Due to more favorable wind characteristics at sea, offshore wind power plants are an interesting and challenging option for meeting future energy demands. In particular, less turbulent wind with higher average velocity enhances energy production and reduces structural fatigue of wind energy structures. In this study, benefits and drawbacks of offshore wind turbine units and power plants are pointed out. Based on the available climate data, sea depths and existing sea traffic routes, two possible wind power plants, i.e. one with fixed and another with floating turbines, are proposed for installation in the Croatian part of the Adriatic Sea. Benefits for the Croatian shipbuilding industry and its economy are pointed out.

\section{KEY WORDS}

$\sim$ Renewable energy

$\sim$ Wind turbine

$\sim$ Offshore wind power plant

$\sim$ Shipbuilding industry

Faculty of Mechanical Engineering and Naval Architecture, University of Zagreb, Croatia

e-mail: neven.hadzic@fsb.hr

\section{INTRODUCTION}

Over the last couple of decades, the strong development of renewable energy technologies has been motivated by the global depletion of fossil fuel reserves. Generally, an energy resource can be considered renewable if it cannot be exhausted and its exploitation does not pollute the environment. Currently, the most frequently exploited renewable energy resources at the global level are the wind, the sun and water. Wind energy is transformed into electricity using wind turbines, as they transform the wind's kinetic energy into the rotational motion of wind turbine rotor blades.

Significant increase in the construction of wind power plants, particularly in the coastal area, can be noted in Croatia. Generally, wind turbine power plants consist of a number of wind turbines placed in an optimum arrangement ensuring favorable flow conditions, i.e. undisturbed wind flow of constant velocity and low turbulence. A relatively constant wind velocity between 5 and $25 \mathrm{~m} / \mathrm{s}$ results in higher energy extraction efficiency and relatively low level of blade and column fatigue. When wind velocity is lower than 5 or higher than $25 \mathrm{~m} / \mathrm{s}$ the operation is restrained, i.e. the rotor is put in the parking position preventing the rotation of the rotor blades, since its continued operation is either unprofitable or there is quite large risk of damage, respectively.

Therefore, wind turbines placed within a wind farm generally have lower operating efficiency and higher fatigue than wind turbines at the upwind edge of a wind farm. In particular, as the flow separates from the wind turbine towers and rotor blades at the leading edge of the wind farm, the wind turbines within 
the farm experience lower wind velocity and higher turbulence. Hence, wind turbines are usually placed at the distance of 4 to 5.5 rotor diameters between the wind-turbine towers in order to improve operating conditions for downwind turbines, (Chamorro and Porté-Angel, 2010).

Nowadays, due to the limited possibilities for wind power plant construction on land, noise problems, visual pollution, low number of available locations with desired wind properties, different commercial difficulties related to land renting or purchasing and the obtaining of necessary legal permits, the development of offshore wind power plants has intensified. Also, due to the nealy flat sea surface, offshore wind has some favorable properties, as for example nearly constant average velocity at hub height with less turbulence, increasing operating efficiency and reducing column and blade fatigue level, enabling the application of longer turbine blades for the same hub height. This trend has been driven by a strong ambition to exploit huge and relatively unused energy potentials, (Bilgili et al., 2011; O'Keeffe and Haggett, 2012).

On the other hand, some of the disadvantages are the maintenance of offshore wind turbines, particularly at high sea, requiring the development of special ships, as well as specialized engineering knowledge and skills required to design and construct such complex engineering structures operating in an aggressive meteorological and corrosive environment. A more detailed overview of the present status, resources, environmental challenges, social impacts and different technical and operational aspects of offshore wind turbines can be found in e.g. (Brennan et al., 2012; Nguyen et al., 2013; Parveen et al., 2014).

The fact that the Croatian Government prohibited the construction of onshore wind turbines on Croatian islands in general, as well as on the mainland in the region within $1000 \mathrm{~m}$ from the Adriatic Coast (Decision on arrangement and protection of protected sea coastal region, 2004) is yet another reason to construct offshore wind power plants in the Croatian part of the Adriatic Sea. Therefore, offshore wind power plants represent a challenging alternative capable of both generating energy and creating new workplaces in the local communities.

An important problem in the Croatian part of the Adriatic Sea is the strong and gusty Bora wind developing at rather high and steep coastal mountains like Velebit and Biokovo. Due to the transient Bora wind, offshore wind turbines are expected to be subject to higher fatigue than onshore wind turbines. Bora's average wind velocity is rarely higher than $17 \mathrm{~m} / \mathrm{s}$ (Belušić et al., 2004), with wind gusts reaching up to $70 \mathrm{~m} / \mathrm{s}$ (Bajić and Peroš, 2005). Another relevant wind developing in the Adriatic is Scirocco with average velocities between $10 \mathrm{~m} / \mathrm{s}$ and $30 \mathrm{~m} / \mathrm{s}$. It usually develops in the southern part of the Adriatic during winter, and in the northern part of the Adriatic during spring (Penzar et al., 2001).
In addition, the numerous Croatian islands form additional obstacles, since their presence decreases wind velocity and enhances atmospheric turbulence. Currently, a comprehensive research of aerodynamics of offshore wind turbines in the vicinity on complex coastal topography is underway within the framework of the FP7-Marinet program - one of the largest offshore renewable energy research projects in history (e.g. Kozmar et al., 2014).

\section{WIND PROPERTIES IN THE CROATIAN PART OF THE ADRIATIC SEA}

The assessment of Croatian wind energy potential based on the computational atmosphere model ALADIN (Bajić et al., 2007; Horvath et al., 2011), of the Meteorological and Hydrological Service, has already been successfully done. The available data include average wind speed and power density at altitudes of 10 and $80 \mathrm{~m}$ above ground level for one year as average quantities within a $2 \times 2 \mathrm{~km}$ square, (Figure 1 ). Since the energy potential of wind turbines is usually determined based on the mean wind speed value at hub height, the results pertaining to the altitude of $80 \mathrm{~m}$ (one of the most frequently applied wind turbine hub heights) are particularly valuable.

Mean wind speed at the altitude of $80 \mathrm{~m}$ is the highest at open sea in front of the town of Pula and the island of Mali Lošinj, open sea in front of the town of Šibenik and the island of Mljet, with values of about $6.5 \mathrm{~m} / \mathrm{s}$. Since, to the authors' best knowledge, wind speed in the Croatian part of the Adriatic Sea has never been measured at open sea, this figure needs to be taken with caution. It is also important to emphasize that the current data does not take into consideration wind pulsation capable of significantly influencing both turbine efficiency and fatigue.

Therefore, the existing data can be applied as the first approximation for loading estimation, while other issues such as turbulence models and high resolution measurement of vertical wind profiles are planned to be resolved in the future based on the 'Wind resources and forecasting in complex terrain in Croatia' project, (Windex home page, http://www.windex.hr), as well as on experimental wind-tunnel simulations, (Kozmar et al., 2014).

\section{DESIGN OF THE OFFSHORE WIND POWER PLANT}

Offshore wind power plant design primarily differs from onshore wind turbine design in the complexity of subprocesses that need to be taken into account and harmonized. Wind turbine design remains in the focus of the problem, as the key factor influencing power plant field array, but all other factors influencing technical and technological implementation and economic effectiveness need to be taken into account as well. It is 


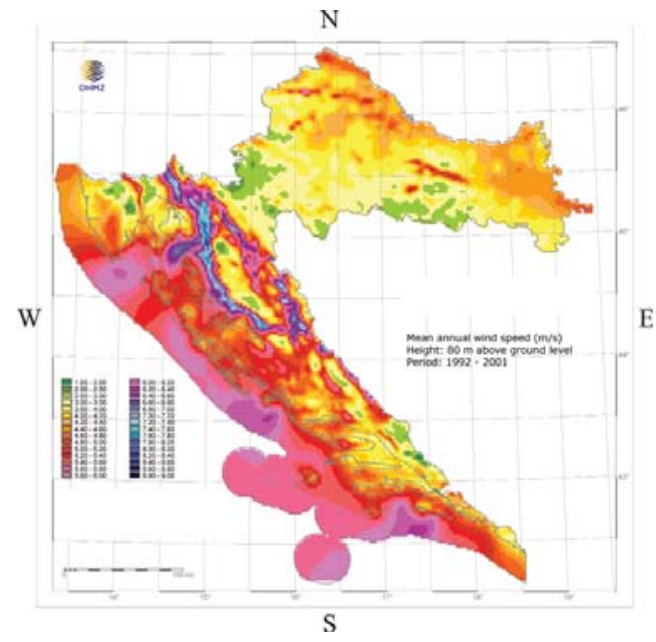

a)

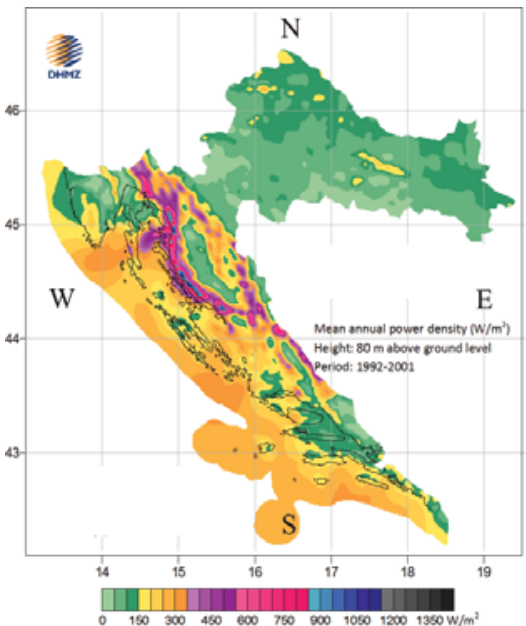

b)

Figure 1.

a) Mean annual wind speed at the altitude of $80 \mathrm{~m}$, b) Mean annual wind power density at the altitude of $80 \mathrm{~m}$. Source: Hrvatski meteorološki zavod, http://www.meteo.hr.

important to point out that the only similarity between onshore and offshore wind turbines or wind power plants can be found in their tower and rotor shape. All other components are different. The construction of onshore wind turbines is mainly based on typical solutions, which is not possible in the case of offshore turbines, since their foundations and subsea tower structure mainly depend on sea depth, sea bottom morphology and composition, and sea currents - the key components influencing the design of the turbine substructure.

Offshore wind power plants can be classified into two basic types, i.e. fixed and floating wind turbines, (Figure 2). The environmental loading of such specific offshore units consists

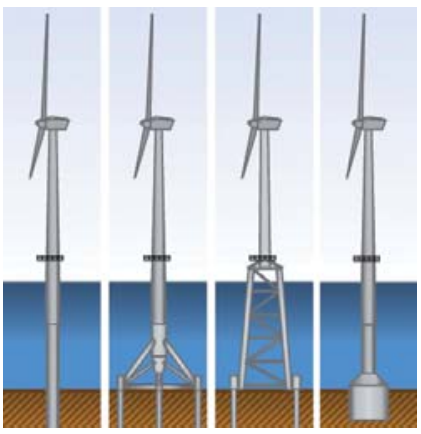

a) of the wind, waves, sea current and earthquakes. Fixed wind turbines are balanced by elastic forces since they are primarily designed based on the stiffness criteria, while in the case of floating turbines, mainly designed based on the resonance criteria, the inertial forces balance the environmental loading. Fixed wind turbines are usually used in configurations where sea depth is not greater than $30 \mathrm{~m}$, mainly with monopod substructure consisting of a single column. The greatest sea depth at which a fixed turbine was ever used was $45 \mathrm{~m}$ (E.ON, 2009). The oil and gas industry has significant experience with designing and mounting of such offshore units.

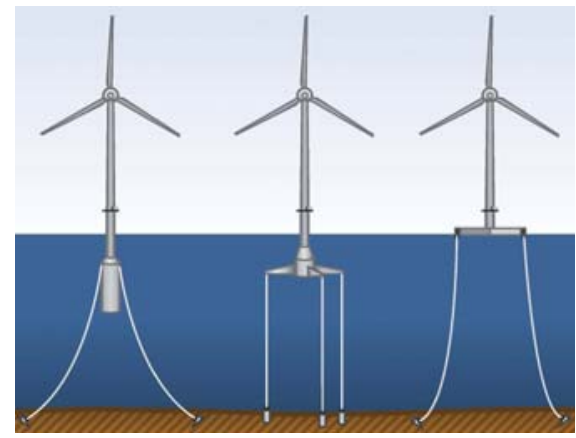

b)

Figure 2.

Different types of a) fixed and b) floating offshore wind turbine supporting structures.

Source: Wiser et al. 2011. 
There are several key issues that need to be addressed when designing an offshore wind power plant and offshore wind turbine:

1. The geographical location of the offshore wind power plant based on the analysis of wind and wave climate, sea bottom profile (bathymetry) and properties (geotechnical testing), the analysis of the existing electrical power supply network and distance from the nearest onshore substations, existing offshore objects (gas, oil, fresh water and sewerage pipelines, telecommunication cables), environmental impact and navigation routes.

2. Wind turbine aerodynamic properties (rotor type and diameter, hub diameter, tower height and diameter) depending on the wind microclimate and the desired power output properties.

3. Wind turbine substructure (fixed or floating turbine) depending on the analyzed wave microclimate, foundation analysis and choice of anticorrosive protection.

4. Energy analysis (substation design, transfer of energy to the nearest onshore substation by underwater cables and its route, i.e. bathymetry).

5. Construction technology, transport, mounting and maintenance of wind turbines.

Based on the wind microclimate analysis, three potential locations in the Croatian part of the Adriatic Sea were selected, i.e. open sea in front of the town of Pula and the island of Mali Lošinj, open sea in front of the town of Šibenik and the island of Mljet. Taking into account the existing sea depths, (Barković, 2014), and navigation routes, (Lušić and Kos, 2006), the open sea in front of the town of Pula and the island of Mali Lošinj seems to be suitable with respect to small sea depth (under $60 \mathrm{~m}$ ) and vicinity of the costal electrical power supply network. However, possible difficulties could emerge due to considerable sea traffic as this is the entrance to the Kvarner Bay. Due to greater sea depth, the location in front of the island of Mljet is not convenient for an offshore wind power plant, since the floating structure of wind turbines in such great depths significantly increases the necessary investment. The optimum location with respect to sea routes is the open sea in front of the town of Šibenik, i.e. between the island of Žirje and the town of Primošten. The drawback of this location is significant sea depth (up to $90 \mathrm{~m}$ ). According to those facts and based on existing wind data it can be concluded that the optimum location for an offshore wind power plant with fixed wind turbines is the open sea in front of the town of Pula and the island of Mali Lošinj, (Figure 3). On the other hand, the open sea between the island of Žirje and the town of Primošten can be considered an optimum location for floating wind turbines.

For the purpose of this study, the potential wind power plant at open sea in front of the town of Pula and the island of Mali Lošinj is projected to consist of twenty fixed wind turbines with hub height of $80 \mathrm{~m}$ and rotor diameter $D=93.2 \mathrm{~m}$ (NWE

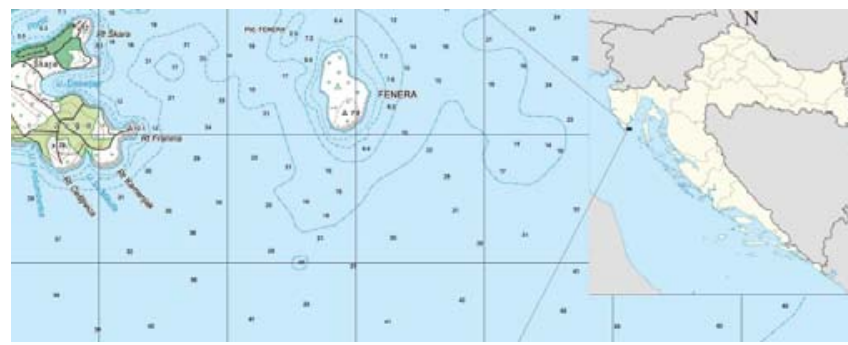

Figure 3

Potential location for a wind power plant with fixed wind turbines (open sea in front of Pula and Mali Lošinj) along with respective sea depths.

Source: Barković, 2014.

Sales - Windmil Sales and Engineering home page, http://www. nwesales.fi). If power coefficient is taken to be approximately $C_{p}=0.4$, air density $\rho=1.2 \mathrm{~kg} / \mathrm{m}^{3}$ and average wind speed $v=6.5$ $\mathrm{m} / \mathrm{s}$, the electrical power produced by a single wind turbine is (Manwell et al., 2009),

$P=\frac{1}{2} C_{p} \rho v^{3} \frac{D^{2} \pi}{4}=449.42 \mathrm{~kW}$

that gives the total amount of 78.73 GWh electrical energy annually, for the whole power plant.

The horizontal distance between wind-turbine towers placed in a staggered pattern within this power plant is taken to be 4 to 5.5 rotor diameters. Accordingly, the area that would be covered by such a plant is about $4 \mathrm{~km}^{2}(2000 \times 2000 \mathrm{~m})$. Based on the selected offshore location and sea depth, the trusted turbine substructure is envisaged for the wind turbines. Similar existing structures for the sea depth of $45 \mathrm{~m}$ are illustrated in Figure 4.

\section{INVESTMENT COST}

The typical $2 \mathrm{MW}$ offshore wind turbine erected in Europe requires an investment of 1.2 - 2 million $€ / M W$, depending on distance from the shore, weather conditions, sea bed conditions and existing electrical power infrastructure, (Bilgili et al., 2011), which is around $50 \%$ more expensive than onshore wind turbines.

Except investment, maintenance costs have significant contribution to the overall operational costs. In case of a fixed offshore wind turbine they range between 125 and $250 € / \mathrm{kW}$, depending on distance from the shore, weather conditions, maintenance methodology, available equipment and auxiliary units such as specialized ships, while in the case of onshore units they are between 70 and $120 € / \mathrm{kW}$ (Wiser et al., 2011).

However, these considerably higher costs are partially compensated by a higher production rate due to higher offshore 


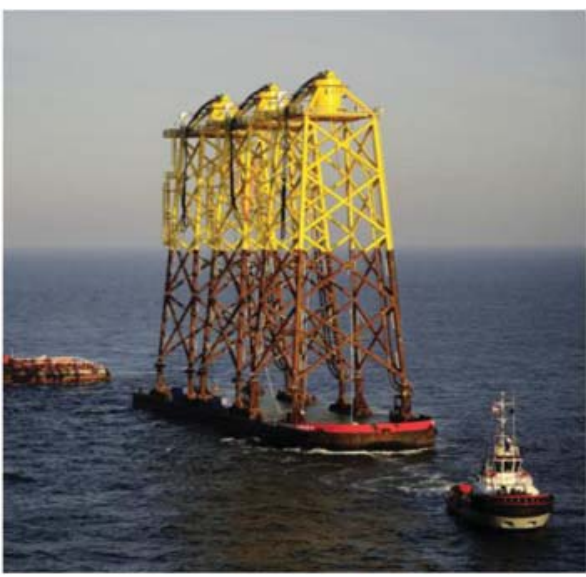

a)

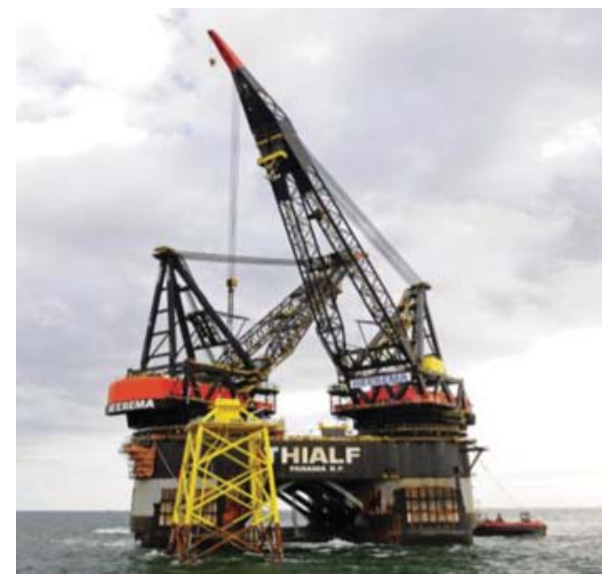

b)

Figure 4.

Fixed wind turbine trusted substructure during a) transport and b) installation, Alpha-Ventus, Germany. Source: E.ON, 2009.

wind velocity. Except for direct operational compensation, higher investment and maintenance can find justification in the development of other accompanying industries, e.g. shipbuilding, employment generation, as well as environmental benefits.

\section{SHIPS USED FOR WIND TURBINE MOUNTING AND MAINTENANCE}

The emergence of offshore wind power plant technology necessitated the development of special ships used for mounting, maintenance and decommissioning of wind turbines. Hence, new technologies were developed not only for that, but also for the purpose of rapid and safe execution of tasks. One of the specialized, unique ships developed for those purposes is a synthesis between jack-up self-elevating platform and a supply vessel. An acronym WTI (Wind Turbine Installation unit) has been widely accepted for those ships. One of the most important design parameters of a WTI ship is its operational speed, since they are designed to economically accomplish special tasks in acceptable environmental conditions. In the case of incoming storm they have to be evacuated into the protected area. In addition to their significant speed and self-elevating property, WTI ships are characterized by relatively large deadweight allowing them to transport all necessary turbine components, and are equipped with a diesel-electric power system with azimuth propellers that enable simple and accurate maneuvering in the vicinity of offshore objects. Automation, redundancy and reliability of power system requirements make WTI ships one of the state-ofthe-art ship types in shipbuilding industry.
In order to be put into operation, WTI's trusted legs need to be mounted on sea bottom to raise the entire ship to the desired height (above sea level) using the self elevating device. In this way, stable working conditions are ensured for crane operations at heights above $100 \mathrm{~m}$, (Figure 5).

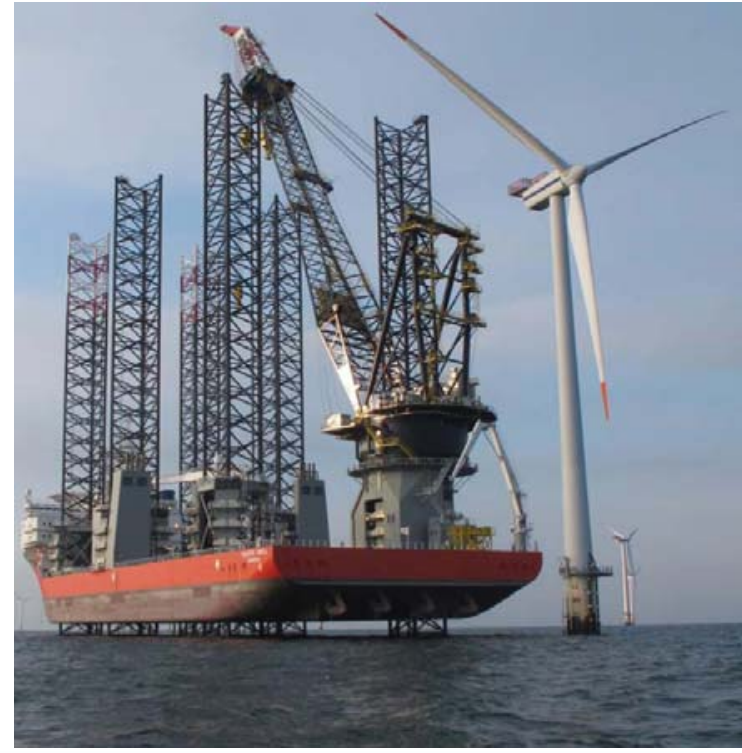

Figure 5.

Self-elevating WTI ship.

Source: Swire Blue Ocean A/S home page,

http://www. swireblueocean.com. 


\section{POTENTIAL BENEFITS FOR THE CROATIAN SHIPBUILDING INDUSTRY AND ECONOMY}

In accordance with global trends and to ensure new business opportunities, the Croatian shipbuilding industry has started a process of production diversification. One of the possibilities along those lines is a synergy between shipbuilding and energy industries, since they have some characteristics in common. In particular, the final product dimensions in both industries are similar. They both involve mainly steel and welding, forming, bending and casting processes capable of being performed by the existing equipment in shipyards.

Croatian shipyards have the necessary production capacities (large workshops, cranes etc.) which can easily meet the technological requirements for onshore and especially offshore wind turbine unit production, in particular: towers, nacelle heavy castings, substructures for fixed turbines and floating platforms for movable ones. Also, their strategic geographical location makes them very attractive, since a significant quantity of final products is transported by sea. For the production of some windturbine components, Croatian shipyards could take advantage of governmental and EU renewable energy resource incentives. It needs to be mentioned that the Brodosplit shipyard already has some experience in the production of wind-turbine towers for foreign companies building onshore wind power plants in Croatia. On the other hand, the Croatia-based company Končar developed its own wind turbine with the capacity of $2.5 \mathrm{MW}$, designed for onshore application.
The possible benefits of offshore wind power plants can also reflect on other fields of economy, namely those involving the production, installation and maintenance of such a complex engineering system, placing new challenges in the sense of knowledge and skills required to plan, design and execute the entire project (general design, production planning, installation planning, logistics, engineering supervision, education of specialized staff, maintenance and safety organization). This activity could potentially employ relevant specialized offices, institutions, agencies, universities, and particularly: shipbuilding experts, civil engineering experts (foundations, soil mechanics), geophysicists (wind and wave microclimate), geologists (bathymetry), mechanical and electrical engineers (offshore substation, connection of the energy cable to an onshore substation).

Another advantage is that all required institutions and experts are available in Croatia. If adequately organized, they would be able to offer this very specialized knowledge and expertise to the world market.

The successful completion of a complexengineering project, like an offshore wind power plant, would have significant impact primarily on Croatian shipyards, giving them an opportunity to develop, design and produce specialized complex ships with high added value, e.g.: heavy-lift vessel, wind-turbine installation unit (WTI), jack-up vessel, offshore supply vessel, cable laying ship, dredger and floating crane. Some of those ships are shown in Figure 6.

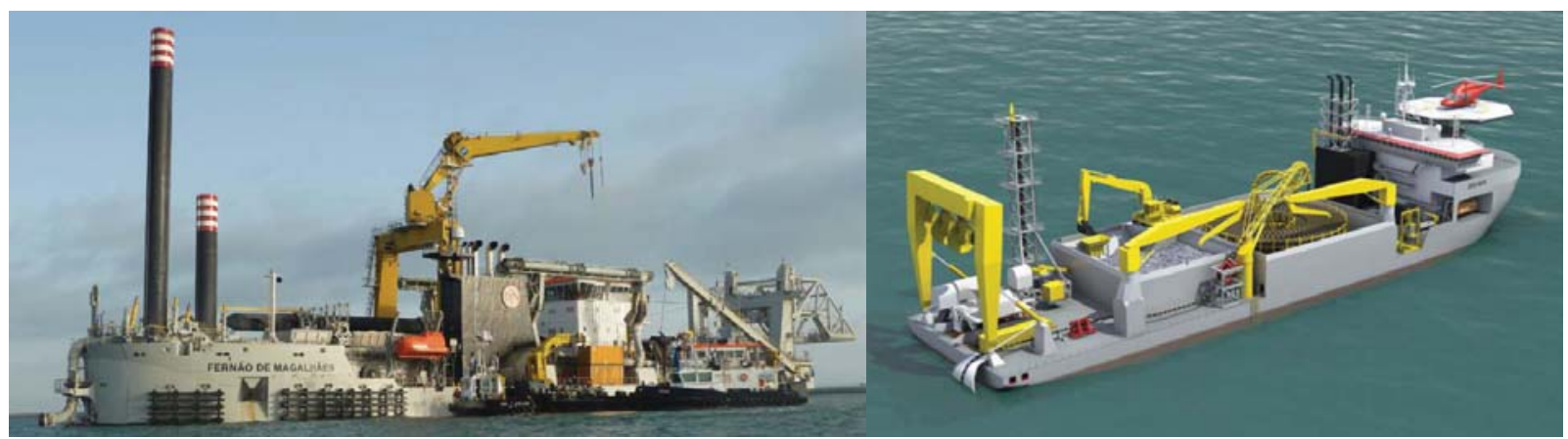

a)

b)

Figure 6

a) Dredger, b) Cable laying ship.

Source: Jan De Nul Gropu home page, http://www.jandenul.com. 
The construction of WTI ships, as a complement to offshore wind turbines, seems to be a privilege of developed economies. However, although none of the Croatian shipyards was able to develop such a product for the global market, some decades ago the Croatian shipbuilding industry managed to manufacture all the necessary elements of advanced WTI technology. One of the examples is the production of the self-elevating platform Labin (Čorić et al., 2004). Its hull was made in Uljanik, pads in 3. Maj, trusted legs with self-elevating device in Brodosplit, with all components assembled in Viktor Lenac. In the 1980s, one similar sophisticated project was also completed, i.e. a floating catamaran crane having the capacity of 12000 kN (Begonja, 1988; Senjanović et al., 1992). At the time it was the largest floating crane in the world. Unit value of such products exceeds standard ship price three to four times, making them very attractive from the manufacturing point of view.

\section{CONCLUSION}

In the past decades, wind energy has globally become a major renewable energy source. While wind energy power plants are commonly built onshore, the most recent trend is to build them offshore due to more favorable wind characteristics at sea. In particular, less turbulent offshore wind with greater average wind velocity enhances energy production and reduces the structural fatigue of offshore wind turbines.

In this study, a possible offshore wind power plant in the Croatian part of the Adriatic Sea was considered. Based on the available data on the wind microclimate, sea depth and sea traffic routes, two potential locations were selected, i.e. open sea in front of the town of Pula and the island of Mali Lošinj for fixed wind turbines, and open sea between the island of Žirje and the town of Primošten for floating wind turbines. The proposed wind energy power plant consists of twenty wind turbines, each with output power of $2.5 \mathrm{MW}$, planned to take up four square kilometers of sea surface.

The total installed power of the considered offshore wind power plant is $50 \mathrm{MW}$, with the annual energy output of 78.73 GWh. This figure was calculated for the average wind speed of $6.5 \mathrm{~m} / \mathrm{s}$, reported in the currently valid wind maps. The calculated annual energy output of this offshore wind power plant is considered not to make a significant contribution to the total energy output of all the Croatian energy sources. Nevertheless, if this project is observed from a general point of view with respect to the Croatian economy, it can easily be seen that such an offshore wind energy power plant could become a major development lever for the Croatian shipbuilding industry and other accompanying fields such as mechanical and electro-industry, civil engineering, geophysics, geodesy.
In addition, planning and design offices, logistic companies, as well as individual experts would gain specialized knowledge and skills required for developing, manufacturing, exploiting and maintaining such complex engineering structures. This would make Croatian economy more competitive and capable of offering relevant services and products to the global offshore market.

The proposed offshore wind power plants would significantly contribute to the Croatian economy since they would enable the acquisition of specialized skills, enhance research and development, especially in the shipbuilding and general industry, and consequently act as a multiplicative factor in the development of new high-tech technologies in Croatia.

\section{REFERENCES}

Bajić, A. and Peroš, B., (2005), Meteorological basis for wind loads calculation in Croatia, Wind and Structures, 8(6), pp. 38-40.

Bajić, A., Ivatek-Šahdan, S. and Horvath, K., (2007), Prostorna razdioba brzine vjetra na području Hrvatske dobivena numeričkim modelom atmosfere ALADIN, Hrvatski meteorološki časopis, 42(42), pp. 67-77.

Barković, Đ., (2014), University of Zagreb, personal communication.

Begonja, D., (1988), A 12000 kN Capacity Catamaran Crane Vessel Design, The 8th Symposium Theory and Practice of Naval Architecture, Zagreb, Croatia.

Belušić, D., Pasarić, M., Pasarić, Z. and Orlić, M., (2004), Quasi-periodic Bora gusts related to the structure of troposphere, The Quarterly Journal of the Royal Meteorological Society, 130(589), pp. 1103-1121., http://dx.doi.org/10.1256/qj.03.53

Bilgili, M., Yasar, A. and Simsek, E., (2011), Offshore wind power development in Europe and its comparison with onshore counterpart, Renewable and Sustainable Energy Reviews, 15(2), pp. 905-915., http://dx.doi.org/10.1016/j.rser.2010.11.006

Brennan, F. P., Falzarano, J., Gao, Z., Landet, E., Le Boulluec, M., Rim, C. W., et al., (2012), Offshore renewable energy, in: Fricke, W., Bronsart, R. (eds.), 18th International Ship and Offshore Structure Congress (ISSC 2012), Schiffbautechnische Gesellschaft, Hamburg, September 9 - 13, Vol. 2, pp. 153-199.

Chamorro, L. P. and Porté-Angel, F., (2010), Effects of Thermal Stability and Incoming Boundary Layer Flow Characteristics on Wind Turbine Wakes: A Wind Tunnel Study, Boundary Layer Meteorology, 136(3), pp. 515-533., http://dx.doi.org/10.1007/s10546-010-9512-1

Čorić, V., Mravak, Z., Ćatipović, I., Reljić, M., Slapničar, V., Uroda, T., Topić, M., Jurišić, P. and Ban, M., (2004), Pregradnja samopodizne platforme tipa Levingston $111 \mathrm{C}$ za nove tržišne uvjete; SORTA 2004-XV Simpozij-Teorija i praksa brodogradnje, Plitvice, Croatia, October $21-23$.

Decision on arrangement and protection of protected sea coastal region, (in Croatian), (2004), Narodne Novine (Official Gazete).

E.ON, Offshore Wind Energy Factbook, December, 2011., available at: http:// www.eon.com/content/dam/eon-com/en/downloads/e/EON_Offshore_Wind_ Factbook_en_December_2009.pdf

Hrvatski meteorološki zavod home page, available at: http://www.meteo.hr, [accessed 1 February 2014.]. 
Horvath, K., Bajić, A. and Ivatek-Šahdan, S., (2011), Dynamical Downscaling of Wind Speed in Complex Terrain Prone to Bora-type Flows, Journal of Applied Meteorology and Climatology, 50(8), pp. 1676-1691.

http://dx.doi.org/10.1175/2011JAMC2638.1

Jan De Nul Gropu home page, availabe at: http://www.jandenul.com, [accessed 5 January 2014.]

Kozmar, H., Allori, D., Marino, E., Bartoli, G. and Borri, C., (2014), Wake characteristics of an offshore wind turbine in the vicinity of a coastal mountain. 13th Conference of the Italian Association for Wind Engineering, Genoa, Italy, June 22-25.

Lušić, Z. and Kos, S., (2006), Glavni plovidbeni putovi na Jadranu, Naše more, 53(5-6), pp. 198-205.

Manwell, J., Mcgowan, J. and Rogers A., (2009), Wind Energy Explained: Theory, Design and Application, New York: John Wiley \& Sons.

Nguyen, T. H., Prinz, A., Friisø, T., Nossim, R. and Tyapin, I., (2013), A framework for data integration of offshore wind farms, Renewable Energy, 60(C), pp. 150-161., http://dx.doi.org/10.1016/j.renene.2013.05.002

NWE Sales - Windmil Sales and Engineering home page, available at: http://www. nwesales.fi, [accessed 2 January 2014.].

O'Keeffe, A. and Haggett, C., (2012), An investigation into the potential barriers facing the development of offshore wind energy in Scotland: case study - firth of forth offshorewindfarm, Renewableand SustainableEnergy Reviews, 16(6), pp.3711-3721., http://dx.doi.org/10.1016/j.rser.2012.03.018
Parveen, R., Kishor, N. and Mohanty, S. R., (2014), Off-shore wind farm development: Present status and challenges, Renewable and Sustainable Energy Reviews, 29(1), pp. 780-792.,

Penzar, B., Penzar, I. and Orlić, M., (2001), Weather and climatology in the Croatian part of the Adriatic Sea, (in Croatian), Zagreb-Koprivnica-Split: Hrvatski hidrografski institut.

Senjanović, I., Čorić, V. and Begonja, D., (1992), Structure Design of a Catamaran Crane Vessel, Brodogradnja, 40(1-2), pp. 21-34.

Swire Blue Ocean A/S home page, available at: http://www.swireblueocean.com, [accessed 4 January 2014.].

Windex home page, available at: http://www.windex.hr, [accessed 5 January 2014.].

Wiser, R., Yang, Z., Hand M., Hohmeyer, O., Infield, D., Jensen, P. H., et al., (2011), Wind energy, in: Edenhofre, O., Pichs-Madruga, R., Sokona, Y., Seyboth, K., Matschoss, P., Kadner, S., Ywickel, T., Eickemeier, P., Hansen, G., Schlömer, S. and Von Stechow, C., (eds), IPCC Special Report on Renewable Energy Sources and Climate Change Mitigation, Cambridge, UK: Cambridge University Press, pp. 535-607. 